\title{
击
}

\section{Geleentheidswoord ${ }^{1}$ Ons tyd - 'n tyd vir verwondering?}

Sou ons die tyd waarin ons leef, 'n tyd van verwondering kan noem? Ek dink so 'n vraag sal beslis reaksievrae ontlok: lemand sou byvoorbeeld vra: Kan ons tyd werklik 'n tyd van verwondering wees? Moet ons nie liewer praat van 'n tyd van verwonding nie? Mense sterf immers in ons land en in ons strate en tuis sukkel hulle nabymense voort met emosionele en ander wonde. Dalk sal ons eerder wou beklemtoon dat ons tyd 'n tyd is van politieke druk en van korrupsie. Ons sien immers daagliks dat korrupsie geboorte skenk aan hofsaak op hofsaak. Miskien nog 'n stem sal hoorbaar word en sê dat ons tyd ' $n$ tyd is van voortdurende verandering sommige veranderinge sinvol, maar ander baie pynlik.

Ek wil graag vanuit 'n sekere hoek kyk na die tyd waarin God ons gestel het - die tyd wat ons het om te lewe en te werk, te studeer en bedienaar van die Woord te wees. Eers gaan aandag gewy word aan Bybelse perspektiewe op tyd en tweedens aan Bybelse perspektiewe op verwondering in ons tyd.

\section{Bybelse perspektiewe op tyd}

As 'n mens kyk na die begrippe wat die Bybel gebruik om tyd aan te dui, is dit asof jy in 'n huis met baie vertrekke instap. In daardie huis woon 'n hele aantal broers of susters saam. Hulle lyk soms nogal baie na mekaar, maar tog het elkeen 'n eie aard en plek. So is dit ook met die uitdrukkings wat tyd aandui in die Bybel. Soms kom hierdie uitdrukkings ná aan mekaar wat betekenis betref en tog het elkeen 'n bepaalde betekenisnuanse.

Ek wil graag drie begrippe vir tyd uitlig om sodoende 'n wyer perspektief te kry op die tyd waarin God ons gestel het.

1 'n Verkorte weergawe van die geleentheidswoord gelewer tydens die Fakulteit Teologie en die Teologiese Skool van die Potchefstroomkampus (NWU) se promosieplegtigheid op 16 November 2005. By dieselfde geleentheid het prof. C.J.H. Venter se emeritusverklaring plaasgevind. 


\section{- Reeds en nog nie}

Een van daardie uitdrukkings vir tyd word gebruik in Romeine 12:2 waar Paulus die gemeente vermaan: "Moet nie aan hierdie sondige wêreld gelykvormig word nie ..." Vir "sondige wêreld" gebruik Paulus 'n tydsaanduiding wat ons ook sou kon vertaal met bedeling of eeu. Paulus bedoel dus: Moet nie aan hierdie sondige bedeling gelykvormig word nie. Bedeling as tyd is dus 'n aanduiding van 'n langer tydperk. In Romeine 12:2 word juis bedoel 'n tydperk soos die tyd vóór Christus se koms en die tyd ná Christus se koms. Die tyd voor Christus se koms word meermale aangedui as die "sondige bedeling", met ander woorde die tyd waarin die bedeling van verlossing nog nie konkreet deurgebreek het in die geboorte en verlossingswerk van Christus nie. Die bedeling ná Christus en dus ook die tyd waarin ons leef, word weer gekenmerk deur die fasette van reeds en nog nie. Verlossing is reeds bewerk, maar in ons tyd breek dit nog nie finaal deur nie. Die nuwe lewe is reeds daar, maar die finale moet nog kom. Die lente is reeds daar, maar die volle somer moet nog kom. Gedurende die lente ervaar ons dikwels ook nog koue dae as nadraai van die winter. Sheila Cussons het in een van haar gedigte gesê: ons leef in hierdie bedeling "tussen eina en amen" - tussen die reeds en die nog nie.

Die begrip tyd in die betekenis van bedeling bring die volgende aspekte van tyd na vore: Tyd is tans nog ja en nee; reeds vervul, maar nog nie finaal vervul nie. In ons tyd is daar nog misverstande, egskeidings, aanrandings en bedrog. Hierdie negatiewe verskynsels is nog manifestasies van die sondige bedeling wat oorloop in die nuwe bedeling. In hierdie tyd van oorvleueling van reeds en nog nie is daar egter ook wonderlike deurbrake van God. Dink byvoorbeeld aan die geval van 'n kwynende stadsgemeente: 150 lidmate wat binne ' $n$ jaar groei na meer as 300 as gevolg van uitreik-aksies en nood wat raakgesien is.

\section{- Gister en vandag}

'n Verdere aspek van tyd wat in die begrip bedeling belig word, is ons visie op gister en vandag. Die gisters in ons kerke en in ons land se bestaan het dinge na vore gebring waaroor ons verwonderd staan. Maar gister was ook die tyd van nog nie. Tydens die gisters van ons geskiedenis het ook dinge plaasgevind waaroor ons ons skaam en verootmoedig. Tyd hou dus ook in: dank God oor die verlede, maar moet die verlede nie net verheerlik nie. Ons kan wel uit die verlede leef en leer, maar ons kan nie in die verlede bly leef nie. 


\section{- Meetbare tyd}

'n Volgende aanduiding wat in die Nuwe Testament vir tyd gebruik word, dui meetbare tyd aan. Tyd kan dus verdeel word in dae, weke, maande jare. Maar tyd snel ook af op 'n eindpunt. Tyd bly as 't ware oop tot ' $n$ bepaalde aankomspunt bereik is. Hiervan word gepraat in Lukas 1:57 waar gestel word: "Toe die tyd gekom het (vol geword het) dat Elisabet se kind gebore moes word ..." Dieselfde uitdrukking vir tyd word ook gebruik in Galasiërs 4:4: "Toe die tyd wat God daarvoor bepaal het, aangebreek het, het Hy sy Seun gestuur." Agter hierdie oomblik wat aanbreek, lê duisende jare. God het die tyd afgemeet en toe laat gebeur dit waarop hy alles laat afstuur het.

Ons studie as bedienaars van die Woord beslaan in tyd normaalweg ses jaar. Die jare hier aan die Teologiese Skool en binne die Fakulteit Teologie is God se afgemete tyd wat Hy gebruik vir toerusting. Daarna breek promosiedag aan. Die studietydperk hier is verby. God bepaal nou 'n tyd vir 'n volgende taak.

\section{- Die beslissende oomblik}

Die laaste begrip vir tyd wat ek kortliks wil behandel, is die woord tyd waarvan ons lees in Prediker 3. In vers een stel die Prediker: "Elke ding het sy vaste tyd." In die 1953-vertaling staan: "Daar is 'n tyd vir alles." Paulus skryf in Romeine 5:8: "Op die bestemde tyd het Christus vir die goddeloses gesterf." Tyd het hier die betekenis van die regte tyd, die groot oomblik, die beslissende tydstip - amper soos wat aan Israel gesê is: "Vandag, as julle sy stem hoor, moenie julle harte verhard nie ...", want daar kom nie weer so 'n oomblik nie. Tyd laat as 't ware iets gebeur. As 'n vuurpyl die ruimte ingestuur word, vind daar ' $n$ aftelling plaas. As alles goed verloop, stel die finale sekonde die aksie in werking en die ruimtetuig vertrek.

Hierdie betekenisnuanse van tyd fokus veral daarop dat tyd nie goed of sleg is nie. Elke oomblik is God se tyd en elke oomblik is 'n beslissende tydstip. Daar kom nooit weer presies so 'n oomblik of geleentheid nie. Doen die regte ding op die regte tyd, maar doen ook dinge reg op die regte tyd.

Tyd is dus wonder-lik, want tyd is God se tyd, die bedeling waarin wat stukkend is reg gemaak kan word, want die Heilige Gees maak ons nou reeds nuwe mense. God se tyd is ook afgemete tyd waarin God 'n pad met ons loop tot op 'n bepaalde eindpunt. Tyd is ook God se groot oomblik, die beslissende, ingrypende tyd. Daarom wek God se tyd verwondering by ons. Maar wat is verwondering en wat kan dit teweegbring? 


\section{'n Enkele Bybelse perspektief op verwondering}

Met die uitdrukkings wat veral in die Nuwe Testament gebruik word om verwondering uit te druk, is dit ook soos met die begrippe wat tyd uitdruk. Die begrippe is elkeen verskillend, maar met 'n eie nuanse. Daar is begrippe wat veral die volgende op die oog het: ekstase of buite jouself wees oor 'n wonderlike ding wat gebeur het. 'n Volgende uitdrukking bring die aspek van verbasing na vore, terwyl 'n derde uitdrukking veral dui op stille verwondering.

\section{- Verwondering as reaksie op Jesus se optrede}

Ek wil graag die aspek van verwondering nader toelig uit Lukas se weergawe van die jeugjare van Jesus. Dit bly opvallend dat die uitdrukking om te verwonder veral in die Evangelie van Lukas voorkom. Hy gebruik die uitdrukkings vir verwondering telkens nadat Jesus 'n wonderwerk, byvoorbeeld 'n genesingswonder, gedoen het - juis om die reaksie van mense op Jesus se wonderdaad te verwoord. Tog kom die begrip verwondering ook in die geboortegeskiedenis en veral in Lukas se beskrywing van Jesus se jeugjare voor. Hierdie feit is opvallend omdat ons eintlik bitter min weet van Jesus se jeugjare. Ons het in Lukas 2 die laaste beskrywing van Jesus se jeugjare. In hierdie gedeelte word verhaal wat gebeur het in die tempel waar Jesus as twaalfjarige seun by die Skrifgeleerdes sit. Hierna weet ons niks verder van Jesus se jong lewe nie. Ons ontmoet Hom weer in die Evangelies op die ouderdom van 30 jaar as Hy preek en wonders doen en uiteindelik sterf en opstaan.

Vir ons doeleindes en om 'n perspektief te bied op verwondering, is Jesus se optrede in die tempel by die Skrifgeleerdes van belang. Hierdie insident word beskryf in Lukas 24:1-52. Hierin is veral verse 46 en 47 van besondere belang: "Na drie dae het hulle (Jesus se ouers) Hom by die tempel gekry waar Hy tussen die (Skrif)geleerdes sit en na hulle luister en hulle uitvra" (vers 46).

\section{- 'n Tipiese leersituasie}

Ons het hier met 'n tipiese leersituasie te doen. Dié wat leer of die onderrig gee, is die Skrifgeleerdes of die wetsgeleerdes. Hulle moes ná die ballingskap vir die Jode in Jerusalem die wet van God voorlees en verklaar. Ook moes die Skrifgeleerdes die Jode opskerp om stip by die wetsbepalings te bly, sodat straf soos die ballingskap nie weer oor hulle sou kom nie. Gedurende 'n onderrigsessie het ' $n$ Skrifgeleerde op 'n verhogie gesit en sy leerlinge het by sy voete gesit of langs hom gestaan. Die Skrifgeleerde was die leermeester. Jesus, die kind van 12 jaar oud, is in Lukas se beskrywing die 
leerling. Wat was Jesus se reaksie in hierdie leersituasie? In hierdie Skrifgedeelte staan drie aksiewoorde om die aktiwiteit van Jesus uit te druk: Hy het gesit ('n tipiese leerlinghouding), Hy het geluister en Hy het die Skrifgeleerde uitgevra. Ons kan byna sê dat ons hier te doen het met ' $n$ situasie van kennisoordrag: om met gespanne aandag te sit, fyn te luister en vrae te vra. Anders gestel impliseer so 'n situasie die volgende: om rustig te wees, in te neem en dan respons te lewer (vrae te stel).

Dit is egter hierdie sit, luister en vra van Jesus, die leerling, wat 'n reaksie van die geleerdes ontlok. Lukas sê hulle was verbaas (dit wil sê verwonderd, buite hulleself) oor Jesus se insig en antwoorde. Verwondering word hier gewek deur Jesus se skerpsinnige vrae en besondere insig. Verwondering kan dus gewek word deur iemand anders se blyke van kennis. Maar hierdie reaksie impliseer beperkte, kortstondige verwondering. Dit is vreeslik ironies dat dit juis die Skrifgeleerdes was wat hulle so verwonder het oor Jesus se insig. Dit was mos ook die Skrifgeleerdes van wie in Lukas 6:6-11 die volgende geskryf word nadat Jesus die man met die gebreklike hand gesond gemaak het op 'n Sabbatdag: "Hulle het rasend van woede geword en onder mekaar geredeneer oor wat hulle Jesus sou aandoen" (Luk. 6:11).

Die Skrifgeleerdes staan verwonderd oor Jesus se kennis, maar word woedend vir die Bron van kennis. Verwondering kan woede word as jy bly vaskyk teen die verkry van kennis, as jy verwonderd bly oor Jesus se insig, maar by Jesus self verbykyk. Dan is ons verwonderd oor wat Jesus sê, maar nie oor wie Hy is en oor wat Hy kom doen as Verlosser van die wêreld nie.

\section{Kennis alleen kan by ons beperkte verwondering wek}

Kennis alleen, ook teologiese kennis, kan ons net by beperkte, verwondering bring. Die tragiek is dat 'n wetenskaplike hom of haar kan verwonder oor Jesus se insig sonder om hom of haar te verwonder oor wie Jesus is. Kennis van God sonder om God te ken, is dor en beperk.

\section{Ten slotte}

Vanaand staan ons studente en ook ek self, by 'n oorgang in die tyd. Vir 'n afgestudeerde student beteken dit áántree in die krag van jou jeug; toetree tot die saailand van die Koninkryk om met daadkrag en entoesiasme die genadeboodskap van die evangelie uit te strooi. Die tyd wat vir ' $n$ Woordbedienaar uitgemeet word, bring ook die 
opdrag om met oorgawe en verwondering in die bedding van die Koninkryk te saai, nat te lei en te versorg. In die besef van wat Jesus gedoen het, sal ook ons as Woordbedienaars verwonderd staan oor die wyse waarop graankorrels mettertyd ontwikkel, ryp word en geoes kan word. Ons eie verwonderde waarneem van ' $n$ resultaat kan alleen plaasvind as ons ook verwonderd is oor die Bron van groei, as ons verwonderd is oor Hom wat ons in 'n spesifieke tyd geplaas het. As ons God én sy vingermerke in die tyd waarneem, sal dit ons steeds verwonderd laat.

Ek self staan ook by 'n oorgang in die tyd - aftree, maar ook óórtree na 'n nuwe tydperk in my lewe. Ook aftreetyd is deel van die bedeling van die reeds en die nog nie - die finale vervulling van God se tyd in my lewe lê verder vorentoe. Mag dit my gegun word om in die lewenspan wat nog vir my uitgemeet word, oopoog en verwonderd te leef in die besef van God se werk in die tyd, want God se tyd is inderdaad wonder-like tyd.

\section{C.J.H. (Cassie) Venter}

